\title{
Differences in students' understanding of opportunity process matters for their learning! *
}

\section{Introduction}

Despite different views on opportunities and opportunities identification, there seems to be consensus about the significant role of opportunities in the entrepreneurship process and regarding the success of the entrepreneur (Shane and Venkataraman 2000, Eckhardt and Shane 2003, Gaglio and Katz 2001). However, even though opportunities are regarded as a core element, process or competence in entrepreneurship, only recently has the question of how to teach or learn these opportunity-related competences started to attract scholars (Saks and Gaglio 2002, Corbett 2005, Lumpkin and Lichtenstein 2005). For Kirby (2007), for example, entrepreneurship education requires the development of the abilities to perceive opportunities. Or as Carrier (2007) suggests, opportunity identification is regarded as a basic entrepreneurial competency that should be implemented at the very beginning of the educational process. So far, however, not much research has been devoted to detecting the nexus of education and opportunity process.

One of the reason of that situation might be that the understanding of the opportunity process is confusing and understood differently by different contributors. Depending on the context and aims, researchers focus on opportunity identification, recognition, discovery or exploitation. Opportunity may be identified (Ardichvili et al. 2003), recognized (Shane and Venkataraman 2000), developed and generated (Alsos and Kaikkonen 2004), discovered and created (Holcombe 2003, Alvarez and Barney 2007). Some authors argue that opportunities 'exist out there' in the form of unmet needs, unsolved problems, or inefficient processes and it is the job of the entrepreneur to uncover these opportunities (Aldrich and Cliff, 2003; Kim, Aldrich and Keister, 2003; Shane, 2003; Gartner et al 2004). Others posit opportunities as a product of one's mind (Shane and Venkataraman 2000; Ardichvili et al. 2003; Gartner et al. 2003). The differences in understanding of opportunity process can be drawn from the nature of an opportunity and its process as well as the nature of human involvement.

Considering the nature of an opportunity Gaglio (2004) identifies three different entrepreneurial opportunities with respect to the way and kind of opportunity; that is 
imitative, incremental and innovative opportunity. Sarasvathy et al. (2003) distinguish three market driven approaches to opportunities: allocative, discovery and creative one. By understanding opportunity as a gap between technological innovation and market their division focuses mainly on pre-conditions of opportunity existence and is thus problematic considering both learning and teaching processes. They do not include human factors in their definitions. Actually an individual does not appear in their allocative view at all, in discovery and the creative view it appears but is only treated as an economic agent.

However, the human involvement in the opportunity process has also been seen as a key to define the nature of the process. As Mc Mullen et al. (2007, p. 278) highlight, the concept of opportunity only finds its meaning in the context of human action. Alvarez and Barney (2007) define this meaning as two alternative theories of entrepreneurial action for the opportunity process: discovery and creation theory. Also Shane and Venkataraman (2000) suggest that the exploitation of opportunity depends on nature of individual that is human involvement. Thus, different ideas of human involvement in opportunity process may result in diverse approaches to opportunity process.

Taking into consideration the learning process, it is also influenced by different understandings of opportunity process. However, we still do not know much about this interplay. How to learn the opportunity process seems to be even a contradictory territory. For example, discovery theory of Alvarez and Barney (2007) describes a situation where opportunities exist as objective phenomena independent of individual action while creation theory assumes that entrepreneurs engage in iterative learning process that ultimately could lead to the formation of an opportunity. On the other hand Corbett (2005) argues, in light of Colby's experiential learning theory, that the best performance in different phases of the opportunity identification and exploitation process is achieved by individuals with different learning modes. This indicates that not only does the opportunity define the learning process, but also the importance of understanding individual learning modes. In a similar vein but in organizational context Lumpkin and Lichtenstein (2005) identified three modes of learning that generate opportunities in entrepreneurial firms. These behavioral, cognitive and action learning approaches each provides different potential opportunities for learning.

Following the scholars, we argue that different opportunity processes lead to a different understanding of the learning process and requires that we understand how the differences 
between the definitions of opportunity and opportunity process influence learning. Considering the learning process, the nature of human involvement is always in focus and thus we assume that different opportunity approaches also involve different ideas of human involvement.

Thus in spite of the efforts to capture and analyze the differences in the understanding of opportunities and its consequences for learning, this field of research still leaves in marginal interplay between opportunity definitions and process as well as the interplay between these and the learning process. However, it is not only a question of definitions but even more importantly of students' understanding of opportunity process.

Accordingly the aim of our research is to better understand different approaches to the opportunity process and their impact on learning opportunity competences. First, we identify different approaches to the opportunity process drawn from their differences in definitions of opportunity and opportunity process as well as differences in the human involvement in each approach. Then we investigate how students understand what opportunities are in the new venture creation process with respect to these different approaches and finally, by studying how these differences emerge in students' understanding of learning opportunity competences, we elaborate what these differences mean for learning practices.

\section{Three approaches to opportunity process}

According to Corner and Ho (2010) opportunity process depends on the general approach to entrepreneurship. The traditional approach to entrepreneurship comes from the economic school which sees it as a market process, and is mainly influenced by the works of Schumpeter, Cantillon, Kirzner and von Mises. However, despite a common market perspective, Schumpeter focuses on the innovativeness of markets seeing the entrepreneur as a disruptive force in an economy, whereas others made an entrepreneur as a human being the center of entrepreneurship. What links Cantillon to Kirzner and von Mises is an equilibrium goal that equilibrium depends on the actions of individuals and a functional approach to entrepreneur. However, even if they agree on idea that the entrepreneur is a human being approaching opportunities, Cantillon sees him as a 'judgment maker', Kirzner as an 'arbitrageur' and von Mises as a 'speculator'. These differences in the conception of the 
nature of human involvement lead to the identification of three different opportunity processes.

The first has its roots in the ideas of Cantillon, who conceived of economy as an organized system of interconnected markets that operate to achieve a kind of equilibrium. (Cantillon, 1931). The institutions of this organized system evolve over time in response to "need and necessity". For Cantillon, the function of an entrepreneur is to assume the risk of uncertainty inherent in market activities and play the role of a coordinator by connecting producers with consumers through rational judgments in an uncertain environment. Cantillon argued that economic science is a pure science of choice, simply because it is built on the purposefulness of human action.

The second and third approaches have their roots in the Austrian economics perspective. They are based on von Mises (1949) thinking and were further developed by Kirzner (1963). They agreed that equilibrium is not a given condition of the economy. Both were interested in the market process, which leads to an equilibrium of the economy. In their view, the entrepreneur is responsible for this process of happening. In Mises' opinion, an entrepreneur creates opportunities by creating disequilibria, while Kirzner's entrepreneur finds opportunities by identifying disequilibria in the market. In particular, Kirzner`s work is influenced by his theory of entrepreneurship and takes its inspiration from the nature of the entrepreneur in von Mises work. He argued that economic science is perceived as activities of human actions and suggested that the market process is driven by individuals who use their cognitive abilities to acquire better shared information about the plans being made by fellow market participants (Kirzner 1973). This dual influence (nature of entrepreneur and cognitive ability) according Sandye (2006) is manifest in the concept of alertness that reflects the tacit nature of the entrepeneur's knowledge in discovery of opportunities.

On the other hand, in Mises' (1949) opinion, the market process is shaped by the daring, imaginative, and speculative actions of entrepreneurs, who identify opportunities for pure profit in conditions of market disequilibria. Mises argued that economic science could not be verified or refuted through the analysis of observable data, but by deriving all definitions of terms from the fundamental proposition that human beings act. To the extent that this can be done, the terms will be useful, to the extent it cannot, they will be discarded or replaced. This methodological apriorism assumed that entrepreneurship always involves human action and 
interaction (Gunning 1996). Entrepreneur means acting man (von Mises, p.255), referring to how actors anticipate, react, and adjust to each others` wants, abilities, knowledge and plans. These roots, their interpretation of opportunities and the nature of human involvement in the opportunity process, leads to three different opportunity approaches: (1) search (Cantillon 1931, Kaplan 2000), (2) discovery (Kirzner 1979, Shane 2000, 2003; Shane and Venkataraman 2000) and (3) action (Mises 1949; Venkataraman 2003) approach (See Table $1)$.

In the first approach, rooted in Cantillon`s thinking, entrepreneurial opportunities are formed when individuals through purposeful, deliberate and conscious search (Drucker, 1998; Zietsma, 1999), identify and filter entrepreneurial opportunity for venture creation (Choi \& Shepherd 2004), or any processes worthy of development (Ardichvili et al., 2003). In this approach, the underlying assumption is that opportunities exist, but are dependent on entrepreneurial action in society (Singh, Hills, \& Lumpkin, 1999). As Ardichvili et al. (2003) argue, in this approach, personal involvement is critical in finding new information and ideas in a multistage process where human involvement plays proactive role in creating a venture. However, the conditions required for search processes to occur require the central artifacts and contexts of business within which decisions are made to be already in place (Sarasvathy, 2001). Individuals are assumed to be rational in their judgments and the conditions under which this approach is made is to search for opportunities as a solution to specific problems or needs. In that sense, searching is the human action of evaluating alternatives and making choices.

The second approach is rooted in Kirzner`s views and posits that opportunities are responses of the individual to changes in environment and exist independently of entrepreneurial action and need to be discovered as objective phenomena. The task of individuals in this approach is to become "alert and sensitive to their environments" (Kirzner, 1997; Shane, 2003) as a result of serendipity effects (Alsos and Kaikkonen, 2004; Ardichvili et al., 2003). This approach assumes that entrepreneurs and non-entrepreneurs must differ in some important ways (Alvarez \& Barney, 2007). Without these differences, anyone could become aware of and then exploit an opportunity. However, if entrepreneurs and non-entrepreneurs differ, then not everyone will know about particular opportunities, or, even if they do, not everyone will be predisposed to exploit them. Individuals have considerably less useful ex-ante information about the opportunities and have to rely on their cognitive abilities to identify opportunities as 
they arise. Individuals may already possess some of this information from previous experience in the environment, or they may collect it as they begin to search for possible opportunities in a recently changed environment (Casson, 1982). Alert (or just lucky) (Barney, 1986) entrepreneurs may even discover opportunities without engaging in a systematic search. In this approach, discovery is a use of individual cognitive abilities to connect different ideas which might contain sources for an opportunity.

The third approach originates in Mises' work and proposes that individuals do not recognize opportunities first and act next (Ardichvili et al., 2003; Choi, 1993; Huber, 2001). Rather, they act, wait for a response to their actions and then they readjust and act again. In this sense, opportunities do not exist until individuals act to create them (Aldrich and Zimmer, 2006; Gartner, 1985; Sarasvathy, 2001; Weick, 1979). Hence, Ardichvili et al., (2003) claim that opportunities are made or created, but not found. Individuals rarely see the end from the beginning (Alvarez \& Barney, 2007). According to Gartner et al. (2003), opportunities are the result of what individuals do, rather than the result of what they see, emphasizing action as a crucial element of venture creation. In this approach, entrepreneurs, during the opportunity process (Baker et al., 2005) have considerably less useful ex-ante information about the opportunities they are forming than is assumed to be in the case of search and discovery approach. Action approach means interpreting the results of experience oriented actions. This approach corresponds to the idea of effectuation of Sarasvathy (2001).

The process moderators in these three approaches are different. In search approach they are based on past knowledge and experiences and in discovery approach past cognitive patterns as for example have elaborated in the work of Baron (2006). In action process past behaviour patterns perhaps best describe moderators for the process. The nature of the process is also different in each approach. In the search approach it is characterized by a linear process from idea to opportunity and further to its exploitation. In discovery approach the process is nonlinear, where the opportunity recognition and its evaluation are intertwined. Finally in action approach different phases of opportunity process are cyclical and intertwined.

The competences needed for proceeding along each of these approaches most obviously are different. Rational thinking based on identified need or problem assumes two kinds of competences that are those needed for identifying or formulating the problem and those needed for developing options and making choices between them. In the discovery approach 
to enhance alertness to changes in environment might be best learned by training to reflect one's own cognitive patterns and thus learning to change them. In action approach experiential learning process that offers an arena to develop and exploit own ideas together with diverse stakeholders needed in the process might best support competences to identify and exploit opportunities in real life contexts to train risk-taking and negotiating competences necessary for forwarding with the process. None of these might be better than others and they may not be mutually exclusive, but they are different and might even take place simultaneously. But instead of a uniform theory these three approaches demonstrate different processes and to understand how to learn opportunity process assumes that we know more about how students understand and experience this process. For that purpose we have chosen case study approach which gives us an opportunity at the same to study how valid these three approaches might be and to investigate what student's expectations for learning opportunity competences are.

Table 1. Three approaches to opportunity identification

\begin{tabular}{|c|c|c|c|}
\hline View & Search approach & Discovery approach & Action approach \\
\hline Roots & $\begin{array}{l}\text { Cantillon } \\
\text { 'judgment maker' }\end{array}$ & $\begin{array}{l}\text { Kirzner } \\
\text { 'arbitrageur' }\end{array}$ & $\begin{array}{l}\text { Mises } \\
\text { 'speculator' }\end{array}$ \\
\hline Opportunity & $\begin{array}{l}\text { Opportunity is a solution to the } \\
\text { problem or need } \\
\text { Opportunities exist, dependent } \\
\text { of entrepreneurial actions }\end{array}$ & $\begin{array}{l}\text { Opportunity is a response of } \\
\text { individual to changes in the } \\
\text { environment } \\
\text { Opportunities exist, } \\
\text { independent of } \\
\text { entrepreneurial actions }\end{array}$ & $\begin{array}{l}\text { Opportunity is a result of } \\
\text { iterative actions of an } \\
\text { individual behaviour } \\
\text { Opportunities do not exist } \\
\text { until entrepreneurs engage } \\
\text { in opportunity process }\end{array}$ \\
\hline $\begin{array}{l}\text { Opportunity } \\
\text { process }\end{array}$ & $\begin{array}{l}\text { Opportunity process is rational, } \\
\text { purposeful and systematic, } \\
\text { aimed at achieving given ends } \\
\text { Nature of process: linear } \\
\text { Process moderators: past } \\
\text { knowledge and experience }\end{array}$ & $\begin{array}{l}\text { Opportunity identification } \\
\text { takes place through } \\
\text { cognitive patterns, } \\
\text { Nature of process: non- } \\
\text { linear } \\
\text { Process moderators: past } \\
\text { cognitive patterns }\end{array}$ & $\begin{array}{l}\text { Opportunity identification } \\
\text { and exploitation are } \\
\text { intertwined } \\
\text { Nature of process: cyclical, } \\
\text { serendipitous or } \\
\text { opportunistic, bricolage } \\
\text { Process moderators: past } \\
\text { behavior patterns }\end{array}$ \\
\hline $\begin{array}{l}\text { Nature of } \\
\text { human } \\
\text { involvement }\end{array}$ & $\begin{array}{l}\text { Human action of evaluating } \\
\text { alternatives and making } \\
\text { choices }\end{array}$ & $\begin{array}{l}\text { Use of individual cognitive } \\
\text { abilities and be alert to the } \\
\text { changes in environment }\end{array}$ & $\begin{array}{l}\text { Proactively interpreting the } \\
\text { consequences as a result of } \\
\text { action based experience }\end{array}$ \\
\hline $\begin{array}{l}\text { Needed } \\
\text { competences }\end{array}$ & $\begin{array}{l}\text { Identifying or formulating the } \\
\text { problem and making the } \\
\text { decisions between alternatives }\end{array}$ & $\begin{array}{l}\text { Alertness to changes in } \\
\text { environment and reflection } \\
\text { on own cognitive patterns }\end{array}$ & $\begin{array}{l}\text { Practicing real life contexts } \\
\text { to better understand on } \\
\text { behavioral patterns }\end{array}$ \\
\hline
\end{tabular}




\section{Methodology}

By adopting a case study approach with multiple informants (Eisenhardt 1989, Yin 1984) we believe we can provide the diversity and specifics needed to identify differences and similarities in students understanding of opportunities and their expectations for learning opportunity competences. As Aaltio-Marjasola (2002) argues, a case study is a special research strategy and approach connected to the previous theories. These theories form a foundation for the analyses and interpretations. As a theoretical foundation we use the three different approaches identified. According to Eisenhardt (1989), case study research focuses on understanding the dynamics present within individual settings and enables particular contexts to be studied in depth, promoting the emergence of new ideas or new interpretations of existing ideas. Here we especially expect to find ideas for learning opportunity competences drawn from different approaches to opportunities.

The case study method also enables a better understanding of the research context. To find a context and students that provide diverse knowledge about opportunity process we chose the group of maste'sr students participating in the course "Introduction to New Venture Creation Process" in Aalto University School of Economics (Finland) assuming that they intended to learn more about opportunities and probably even had experiences of venture creation processes. The general goal of the course is to learn new venture creation competences in various contexts and in multi-disciplinary teams. These include competencies to create, recognize and exploit opportunities, set goals, and negotiate resources needed in the exploitation process and gain project specific entrepreneurship knowledge for planning and managing the venture.

Following Pauwels and Matthyssens' $(2004,128)$ architecture of an elaborative multiple case study design we build our methodology upon four pillars - theoretical sampling, triangulation, analytical pattern-matching logic and analytical generalisation. These cornerstones give us clear guidance on how to conduct the research. Under theoretical sampling, and considering the multiple number of informants (16 students) the case could provide diverse experiences that allow us to identify different patterns of opportunity process. In this regard, the validity of different patterns could be identified for further proceeding towards theoretical generalization. Pattern matching logic is proposed as a general analytical strategy, where events are explained when they are related to a set of other elements, however, in this study, patterns that emerge 
from individual student writings (within-case analysis) are related to other students (theoretical replication). Hence, the phases typical of a multiple case study also can be adopted here in our single case study. Next we elaborate how we approach these four cornerstones.

\section{Theoretical sampling and data gathering}

According to Stake (1995) the first criterion in selecting the cases should be to maximize what we can learn and as Pauwels and Matthyssens (2003) state, to create theory-driven variation and divergence in the data, not to create more of the same. Here, on the basis of the theoretical lenses of three approaches to opportunity identification, we created theory-driven variation by taking the personal experiences of all students into account and supplementing this data with information about their backgrounds. Therefore information-oriented selection of the case was executed in order to achieve as rich and profound information as possible (Flyvbjerg 2006). Diversity of informants (16 students) includes different bachelor's degree backgrounds (business management, economics, management, engineering, informatics, politics and international studies); different working and life experience (international exposure); different nationality (Austrian, Finnish, Russian, Ecuadorian, Czech, Nepalese, German); and different entrepreneurial experiences (non-entrepreneurs, entrepreneurs, serial entrepreneurs). The diverse background of students guarantees an information rich case. Having 16 informants in our case enables the conduct of within-case analysis to be used for richer three-approach construction building. In the assignment students were asked to submit a written assignment on how they want to develop themselves as venture creators at the beginning of a course which was their first course on the entrepreneurship master's programme. They were only asked to concentrate on the reflective side of the topic.

\section{Triangulation}

The types of triangulation followed the two categories identified by Denzin (1984). Investigator triangulation means that several investigators examine the same phenomenon. This was guaranteed by our research team of three with diverse experiences and expertise. Methodological triangulation means that one approach is followed by another to increase confidence in the interpretation. This took place in the analysis process when, after taking a holistic view of the cases, we used textual analyses to identify the differences and similarities and then in the final phase we again compiled coherent stories and then analyzed them according to the previous findings in their unique context. 


\section{Data analysis}

Adopted pattern matching analytical logic is commonly used in disciplines like biology, medicine, linguistics or computer sciences, but not in entrepreneurship research (Pauwels \& Matthyssens 2003, Yin 1984). According to this observational evidence from our multiple informants (students) is referred to our theoretical framework of opportunity identification (three approaches) in two phases (See Figure 1). This enables us to check whether our observational realm might support our theoretical construct.

In the first phase the matching criteria are the same as used in Table 1 that is: understanding of opportunity, opportunity process, and nature of human involvement. Here the students' writings were analyzed deductively according to the three criteria and then matched to the patterns of the three approaches. Thus we can conclude on how well the three approaches fit reality.

In the second phase we identified what students' expectations for learning opportunity competences are drawn inductively from the data. This evidence was then pattern matched with the outcome of the analysis of the first phase. Finally, we summarize our analytical generalization based on the interplay between our theoretical frame and empirical findings.

Figure 1. Methodological framework.

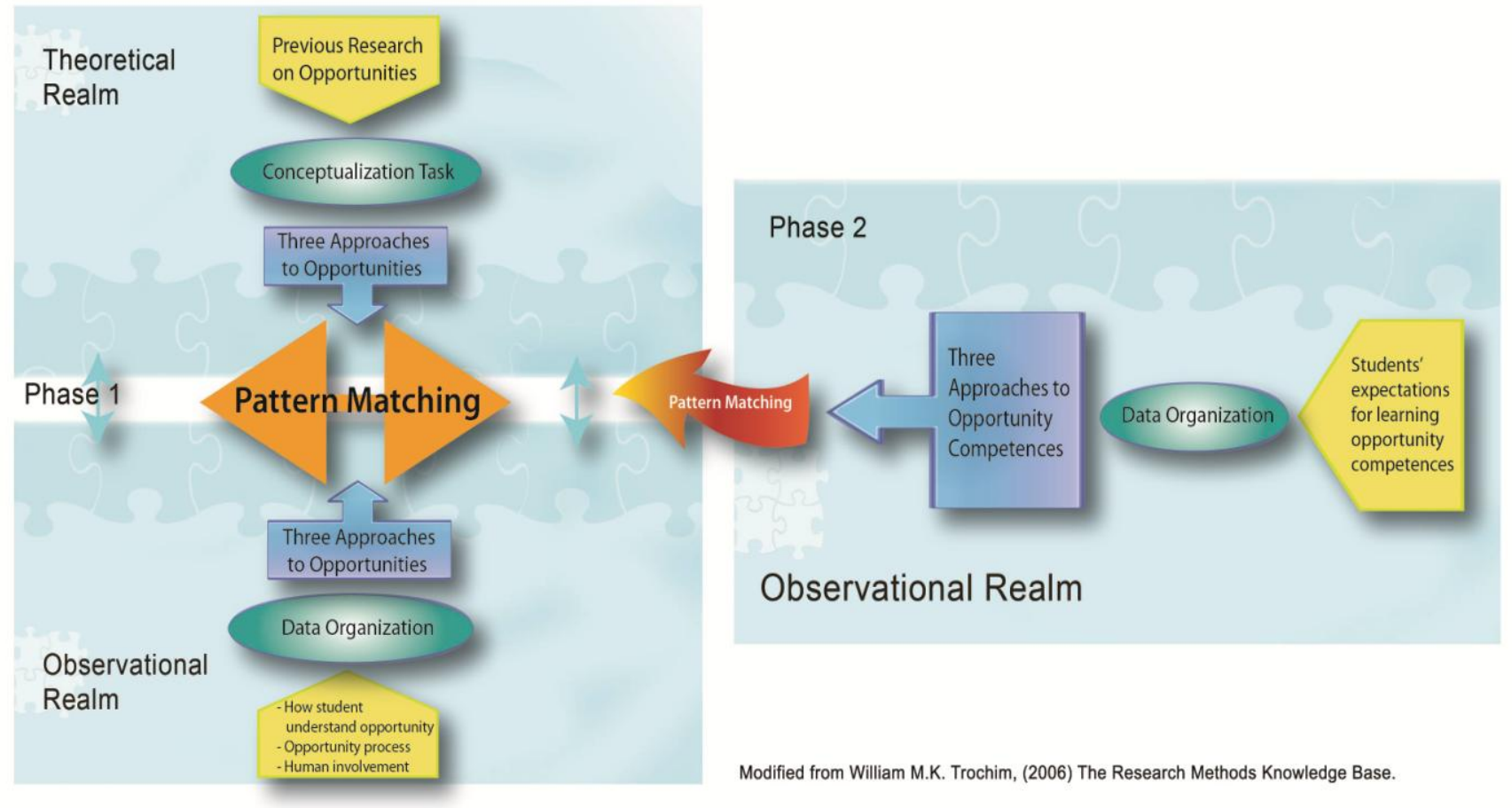




\section{Results}

Pattern matching phase one - Students' understanding of opportunity, opportunity process, and nature of human involvement.

\section{Search approach}

Three out of 16 students $(8,12,14)$ fell into the search approach (see Table 2). Their willingness to create ventures follows their understanding of opportunity as a planned and systematic manner. They see venture creation as a necessity for a particular need and/or improvements in existing businesses. In the course of the process, students believe in evaluating rationally the opportunities to determine whether they meet their venture-related needs and goals. Considering human involvement and process moderators they believe that finding more information and providing rational plans will help them to evaluate and make choices between different ideas and make decision of exploiting opportunity.

Table 2. Search approach

\begin{tabular}{|c|c|c|c|}
\hline Criteria & Student 8 & Student 12 & Student 14 \\
\hline $\begin{array}{l}\text { Opportunity } \\
\text { *a solution to the } \\
\text { problem or need } \\
\text { *exist dependent of } \\
\text { entrepreneurial } \\
\text { actions }\end{array}$ & $\begin{array}{l}\text { Opportunity is "desired } \\
\text { improvement" which may } \\
\text { be achieved } \\
\text { I need to complete the } \\
\text { following steps }\end{array}$ & $\begin{array}{l}\text { Often connected to } \\
\text { some operation } \\
\text { ventures or new } \\
\text { product ventures, } \\
\text { which means proper } \\
\text { technical \TTlor } \\
\text { engineer knowledge.. }\end{array}$ & $\begin{array}{l}\text { "ventures can be created for } \\
\text { some particular need or } \\
\text { existing businesses can be } \\
\text { done better" }\end{array}$ \\
\hline $\begin{array}{l}\text { Opportunity } \\
\text { process } \\
\text { rational, purposeful } \\
\text { and systematic, } \\
\text { aimed at achieving } \\
\text { given ends } \\
\text { based on knowledge } \\
\text { and experience }\end{array}$ & $\begin{array}{l}\text { Is a multi-stage and } \\
\text { repetitive process of } \\
\text { "detecting weakness and } \\
\text { where the improvement is } \\
\text { most needed" } \\
\text { Draw a development plan } \\
\text { for team and individuals } \\
\text { with set goals }\end{array}$ & $\begin{array}{l}\text { identifying the real } \\
\text { risks are very crucial } \\
\text { stages in } \\
\text { development }\end{array}$ & $\begin{array}{l}\text { Is having habit to think how } \\
\text { you can do things better or } \\
\text { faster", for example by } \\
\text { networking or gaining } \\
\text { knowledge }\end{array}$ \\
\hline $\begin{array}{l}\text { Nature of human } \\
\text { involvement } \\
\text { evaluating } \\
\text { alternatives and } \\
\text { making choices }\end{array}$ & $\begin{array}{l}\text { I need to complete the } \\
\text { following steps: ..." } \\
\text { achieved by "creating a } \\
\text { development plan to show } \\
\text { progress" }\end{array}$ & $\begin{array}{l}\text { "it is very essential } \\
\text { to know all the } \\
\text { information, have an } \\
\text { appropriate } \\
\text { knowledge about the } \\
\text { opportunity and } \\
\text { circumstances" }\end{array}$ & $\begin{array}{l}\text { Individual should "broaden } \\
\text { thinking about business } \\
\text { opportunities" to "become } \\
\text { more active with finding } \\
\text { information" }\end{array}$ \\
\hline
\end{tabular}

\section{Discovery Approach}

Four students $(1,3,10,16)$ following the discovery approach, believe that opportunities emerge independent of their action and by responding these changes they can create their ventures. For them it is a result of observing changes in their environment. They describe the 
opportunity process as getting holistic picture that is a consequence of their ability to combine different ideas and simultaneously evaluate their feasibility with respect to markets, thus it is based as process moderator rather on previous cognitive patterns than previous knowledge and experiences per se. Being alert to these changes students think they can find their ventures. As described by students this requires alertness or mindset to those opportunities available for them.

Table 3. Discovery approach

\begin{tabular}{|c|c|c|c|c|}
\hline Criteria & Student no. 1 & Student no. 3 & Student no. 10 & Student no. 16 \\
\hline \multicolumn{5}{|l|}{ Background } \\
\hline $\begin{array}{l}\text { Opportunity } \\
\text { - } \quad \text { a response of an } \\
\text { individual to } \\
\text { changes in the } \\
\text { environment } \\
\text { - exists independent } \\
\text { of entrepreneurial } \\
\text { actions }\end{array}$ & $\begin{array}{l}\text { evaluate the ideas that } \\
\text { came through the } \\
\text { identifying opportunities, } \\
\text { understand the market } \\
\text { potential of the idea }\end{array}$ & $\begin{array}{l}\text { "I am eagerly looking } \\
\text { for excellent business } \\
\text { ideas }\end{array}$ & $\begin{array}{l}\text { Is a process of } \\
\text { "accepting changes as an } \\
\text { opportunity }\end{array}$ & $\begin{array}{l}\text { one must be } \\
\text { inspired, open to } \\
\text { new and creative } \\
\text { thinking. Second, } \\
\text { one must be } \\
\text { motivated. }\end{array}$ \\
\hline $\begin{array}{l}\text { Opportunity process } \\
\text { identification takes place } \\
\text { through cognitive } \\
\text { patterns }\end{array}$ & $\begin{array}{l}\text { Is a process composed of } \\
\text { various stages that due to } \\
\text { possessed skills and } \\
\text { knowledge enables to } \\
\text { "understand the bigger } \\
\text { picture": }\end{array}$ & $\begin{array}{l}\text { I should always find } \\
\text { out new ideas for } \\
\text { ventures and also } \\
\text { bounder their } \\
\text { feasibility and potential } \\
\text { in the specific market } \\
\text { and segment" }\end{array}$ & $\begin{array}{l}\text { to see things from } \\
\text { beginner's perspective" }\end{array}$ & $\begin{array}{l}\text { "by giving order } \\
\text { to processes that } \\
\text { can otherwise } \\
\text { seem like a } \\
\text { complex puzzle } \\
\text { with no clear } \\
\text { starting point" }\end{array}$ \\
\hline $\begin{array}{l}\text { Nature of human } \\
\text { involvement } \\
\text { use of individual } \\
\text { cognitive abilities and } \\
\text { be alert to the changes in } \\
\text { environment }\end{array}$ & $\begin{array}{l}\text { "alertness or swift in } \\
\text { identifying } \\
\text { opportunities" and } \\
\text { capability to understand } \\
\text { the market potential }\end{array}$ & $\begin{array}{l}\text { mindset which makes it } \\
\text { easier to operate your } \\
\text { own business }\end{array}$ & $\begin{array}{l}\text { Individual has to accept } \\
\text { "the way things are" and } \\
\text { "surround with success } \\
\text { models" }\end{array}$ & $\begin{array}{l}\text { "Dynamics } \\
\text { between } \\
\text { traditional } \\
\text { knowledge, } \\
\text { interactive and } \\
\text { critical } \\
\text { brainstorming" }\end{array}$ \\
\hline
\end{tabular}

\section{Action Approach}

Eight out of sixteen students fell into the action approach. All of them underlined the need for doing and practical experience where opportunities are created by constant engagement in the iterative process of developing and implementing opportunities from ideas. The drivers are creativity, passion and willingness to learn from mistakes and failures. These descriptions demonstrate the behavioral nature of entrepreneurs to the effect that individuals respond to the consequences of their actions and readjust to act again. Students evincing this approach believe in practicality and experiencing a real action as a means of identification of an opportunity and creation a venture. In this approach the primary reason for the students to become venture creators is their passion for creating innovations i.e. being able to execute 
things in a way that was not done in the past. The nature of human involvement matches the proposition because students believe in their actions and behavior in interpreting the opportunities that could not have been identified without the series of their actions. The past behaviour patterns also become evident process moderators for these students.

Table 4. Action approach

\begin{tabular}{|c|c|c|c|}
\hline 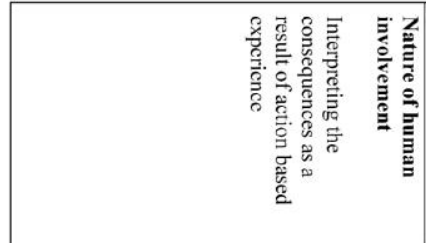 & 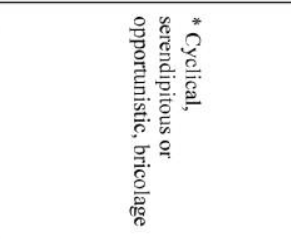 & 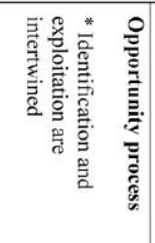 & 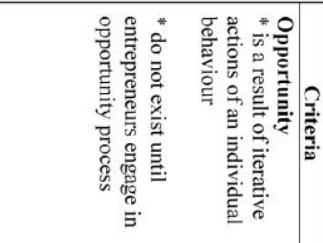 \\
\hline 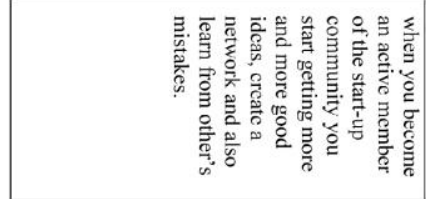 & & 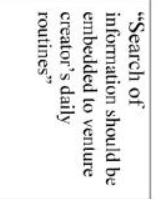 & 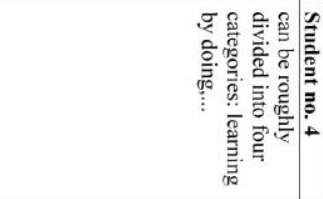 \\
\hline 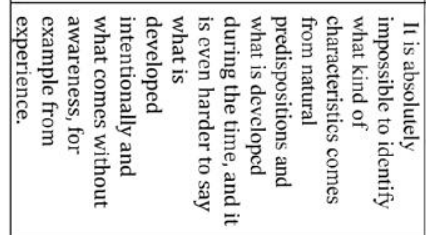 & 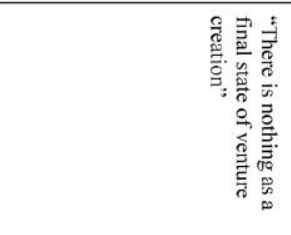 & 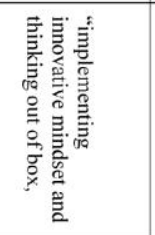 & 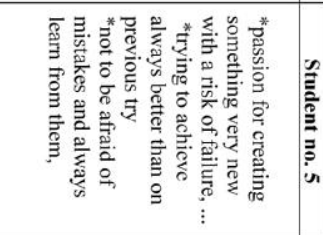 \\
\hline 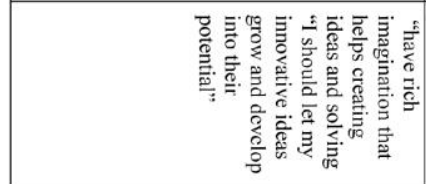 & & 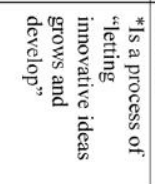 & 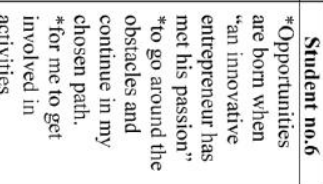 \\
\hline 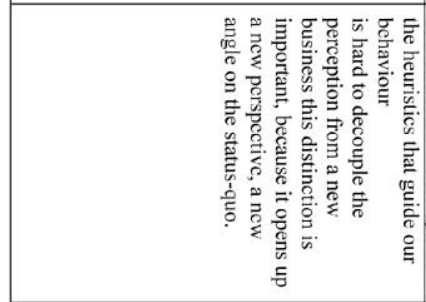 & 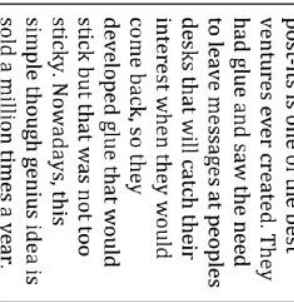 & 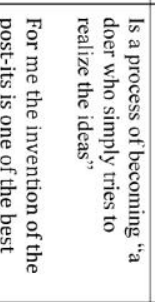 & 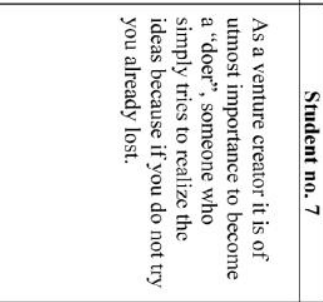 \\
\hline 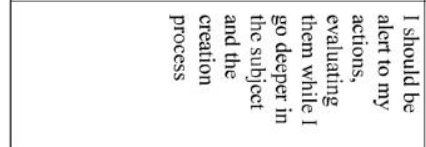 & & 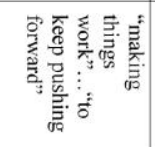 & 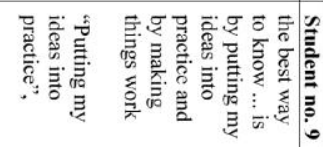 \\
\hline 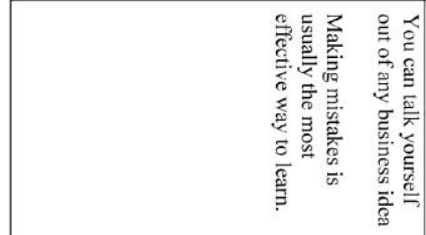 & 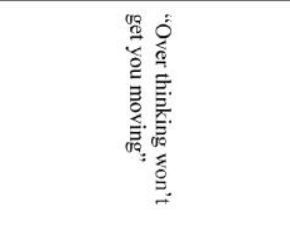 & 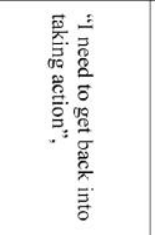 & 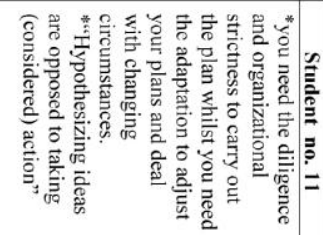 \\
\hline 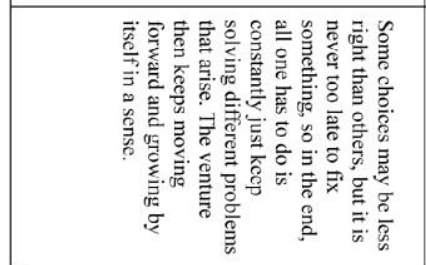 & 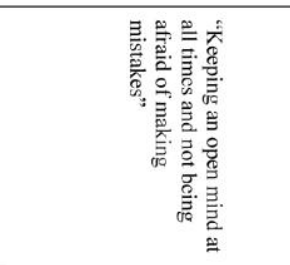 & 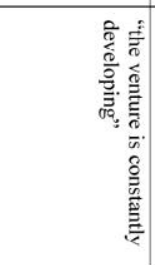 & 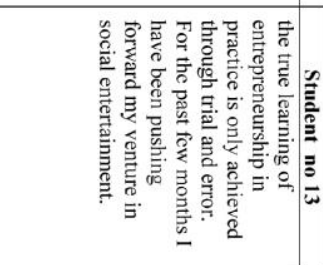 \\
\hline 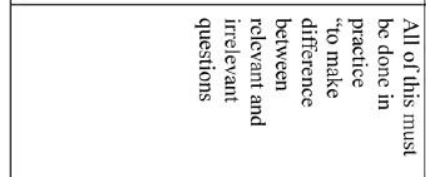 & 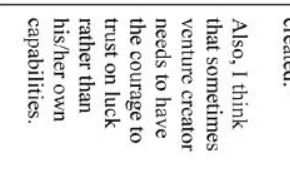 & 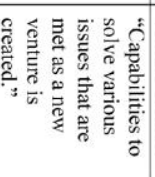 & 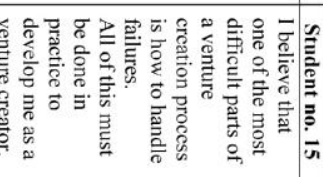 \\
\hline
\end{tabular}


This matching between students' experiences and within three approaches of opportunity identification indicates that it is possible to identify three different approaches thus validating their basic differences; that is understanding of opportunities, their processes and the nature of human involvement.

\section{Pattern matching phase two - Students' perception of learning opportunity competences}

This second phase of pattern-matching is based on our original proposition that if opportunity and opportunity processes are different in the three approaches, the same should relate to learning opportunity competences. Since phase one indicated that it is indeed possible to make a difference between three approaches the second challenge is to understand how these differences influence learning. To study this here we first inductively identify what students' expectations of learning opportunity competences are by drawing their ideas inductively from the data. This evidence then is pattern matched to the outcome of the pattern matching phase one.

Regardless of the approach, students declare that the learning process is an essential part of their development as venture creators. Learning shapes and stimulates their transformation from them-today (being identity) to them-in-future (becoming identity). At present students identify themselves as those who have already some entrepreneurial experience and knowledge, and now try to enhance their competences in order to become a successful venture creator in future. The way they want to achieve it is mainly through a learning process which embraces knowledge absorption, various skills, formal education, interaction with colleagues and networking. However, the way of development and the expectations from learning process to become venture creator vary in each approach.

\section{Search approach}

For students identified under the search approach, the learning process is based on knowledge, information or data availability which are further consequently exploited according to development plans and/or goals. They want mostly to improve their skills and personal attributes in learning rationally to find knowledge in order to make better choices for developing and exploiting opportunities. 
Table 5. Perception of learning opportunity competences for students from search approach

\begin{tabular}{|c|c|c|}
\hline Student no. 8 & Student no. 12 & Student no. 14 \\
\hline $\begin{array}{l}\text { - Identify the important skills and } \\
\text { personal attributes needed for } \\
\text { the particular venture } \\
\text { - Evaluate me and my team in } \\
\text { terms of those needed skills } \\
\text { - Draw a development plan for } \\
\text { team and individuals with set } \\
\text { goals } \\
\text { - Follow up the execution of the } \\
\text { plan to ensure that desired } \\
\text { improvement is achieved } \\
\text { * Repeat the process }\end{array}$ & $\begin{array}{l}\text { Taking the risk and identifying the real } \\
\text { risks are very crucial stages in } \\
\text { development as a venture creator for me } \\
\text { to know all the information, have an } \\
\text { appropriate knowledge about the } \\
\text { opportunity and circumstances }\end{array}$ & $\begin{array}{l}\text { Becoming more active with } \\
\text { finding information, to } \\
\text { acquire better negotiation } \\
\text { skills and get to know the } \\
\text { field that I am really } \\
\text { interested in. I also should } \\
\text { broaden my thinking about } \\
\text { business opportunities. }\end{array}$ \\
\hline
\end{tabular}

\section{Discovery approach}

Students representing the discovery approach expect to be aware of environment they live in and changes that happen in that environment. It allows them to adapt changes into their ideas. They want to have broader perspectives and a bigger picture of the world, all indicating their expectations to develop their cognitive patterns. They believe that alertness and developing mindset would improve their venture creation competences.

Table 6. Perception of learning opportunity competences for students from discovery approach

\begin{tabular}{|c|c|c|c|}
\hline Student no. 1 & Student no. 3 & Student no. 10 & Student no. 16 \\
\hline $\begin{array}{l}\text { 1. better alertness or swift in } \\
\text { identifying opportunities } \\
\text { 2. capability to understand the } \\
\text { market potential of the idea. } \\
\text { 3. understanding of the } \\
\text { patenting process... how to } \\
\text { license the patents to whom } \\
\text { and when. } \\
\text { 4. how to monitor the ventures } \\
\text { that I have already created } \\
\text { to understand the bigger } \\
\text { picture as a venture creator. }\end{array}$ & $\begin{array}{l}\text { an entrepreneurial } \\
\text { and global aspect } \\
\text { and mindset }\end{array}$ & $\begin{array}{l}\text { changing as a person, changing } \\
\text { my beliefs about the world and } \\
\text { my self-image, and integrating a } \\
\text { new system of values which } \\
\text { consistently drive me and my } \\
\text { actions } \\
\text { to develop in myself... accepting } \\
\text { changes as an opportunity to see } \\
\text { things from bigger perspective } \\
\text { the learning process is } \\
\text { continuous }\end{array}$ & $\begin{array}{l}\text { be inspired, open to } \\
\text { new and creative } \\
\text { thinking. Second, } \\
\text { one must be } \\
\text { motivated. The } \\
\text { implementation } \\
\text { phase, especially, } \\
\text { requires grit and } \\
\text { determination. }\end{array}$ \\
\hline
\end{tabular}




\section{Action approach}

Action type of students demand creative and imaginative thinking, letting their ideas appears, grow and change. They do not believe that opportunities are first recognized and then acted upon, but describe the opportunities process as a continuous process of learning and development. They connect venture creation with uncertainty or risk and assume that the possibility of learning from failures and experiences enhance their venture creation competences. They are not afraid of making mistakes; they are interested in others' mistakes and even see it as a way of learning. By trying out many options they call for more courage. Students representing the action approach are also more oriented to other people and networking than students identifying with other approaches. 
Table 7. Perception of learning opportunity competences for students from action approach

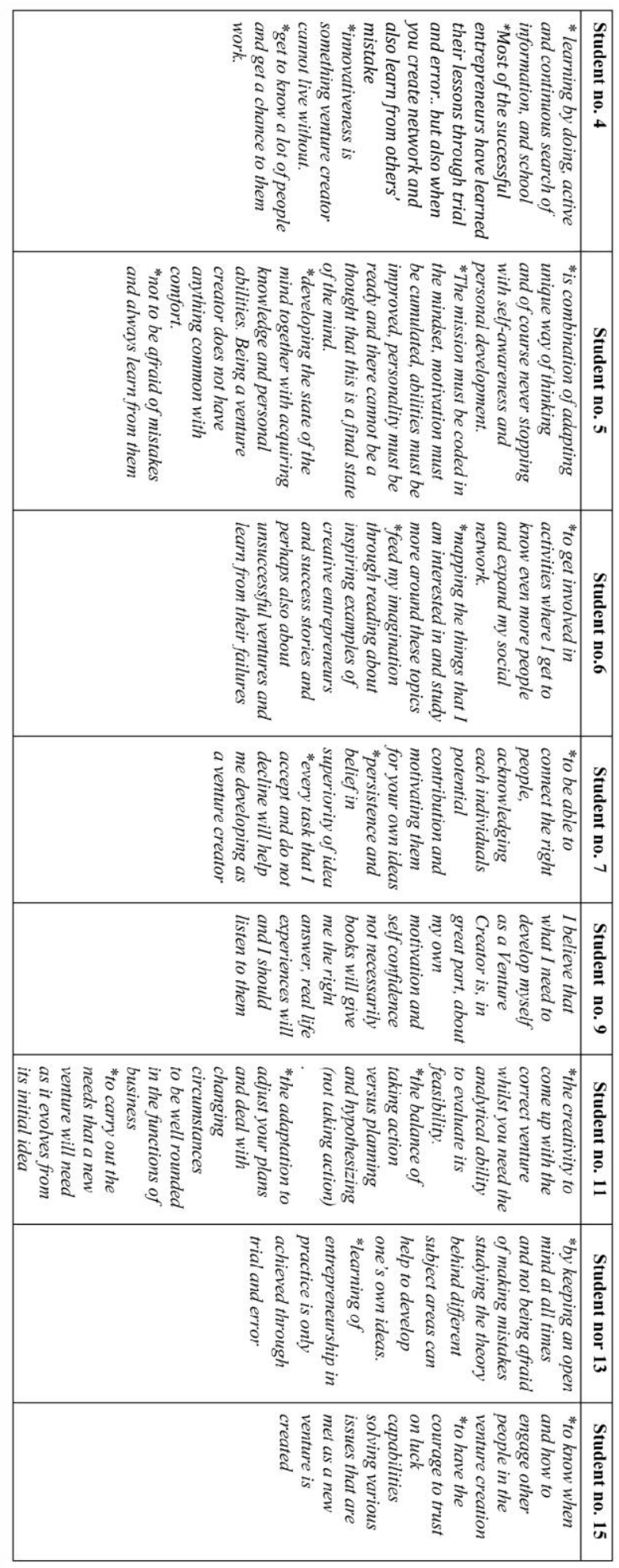


The outcome of this phase of pattern matching analyses indicates that students' expectations for learning opportunity competences consistently follow three different approaches. Thus expectations for learning competences in each category acquire their own unique profile or learning pattern which effect on learning and teaching practices. These differences are elaborated next.

\section{Differences in learning and teaching practices in different opportunity identification approaches}

The outcome of two-phase pattern matching gives us an indication about the differences in learning and detaching practices in three different approaches.

To ask how to learn to identify and exploit opportunities assumes that we can combine opportunity in entrepreneurial process and individual competences. Only then we can start to ponder how to learn or teach them. Thus the competence and the process are intertwined in the learning process. Here we suggest that the process and outcome of the learning intervention fundamentally depends on these definitions.

To enhance those competences needed in the search approach students need to be exposed to processes where problem solving and rational thinking are encouraged. We do not have much information on how students identified the problems, but we can assume that the competence to find and formulate the problem is crucial for this kind of an approach. Thus the tremendous work done in the field of problem based learning in other contexts, for example in medicine and education, might be a suitable approach for teaching in the search approach added with rational problem solving methods as is for example expected in compiling the business plans.

In the discovery approach to find a way to affect on training students cognitive patterns is a complicated challenge. However, we can assume that being aware of one's own cognitive patterns, its possibilities and limitations might help students to increase their awareness and thus provide opportunities to consciously train alertness. The newest developments in the global concept mapping community in education and learning from their recent research might provide some tools for this. Baron's frames of cognitive pattern recognition might serve as a good starting point for this approach. On the other hand to creatively provide ideas needs 
more creative approaches and for example classical mind map techniques and other idea generating techniques could be combined to learning interventions in discovery approach.

Action approach has much in common with the work of Sarasvathy's effectual processes and many ideas could be adopted from that. In some respects a learning frame for this might be the often used Colb's experiential learning model. However, rather than models the main idea and general guidance for this approach is that students are exposed to real life venture creation processes where they actually create and exploit their own ideas and opportunities. Teaching means creating arenas and environment for these interventions and supporting students' own processes. Often what is meant by that is misinterpreted by reducing the opportunity to let students' own ideas prosper. These ideas are summarized in Table 8.

Table 8. Different learning methods of opportunity process.

\begin{tabular}{|l|l|l|l|}
\hline \multirow{2}{*}{} & \multicolumn{1}{|c|}{ Focus on } & \multicolumn{1}{c|}{$\begin{array}{c}\text { Enhanced } \\
\text { competences }\end{array}$} & \multicolumn{1}{c|}{ Tools } \\
\cline { 2 - 4 } & \multicolumn{1}{|c|}{$\begin{array}{l}\text { Students with search } \\
\text { approach }\end{array}$} & $\begin{array}{l}\text { Problem } \\
\text { formulation and } \\
\text { rational problem } \\
\text { solving methods } \\
\text { identification and } \\
\text { formulation } \\
\text { competences and } \\
\text { competences to } \\
\text { provide alternative } \\
\text { solutions for problem } \\
\text { solving and decision } \\
\text { making }\end{array}$ & $\begin{array}{l}\text { Problem based learning and for } \\
\text { example Business plan training }\end{array}$ \\
\hline $\begin{array}{l}\text { Students with discovery } \\
\text { approach }\end{array}$ & $\begin{array}{l}\text { Cognitive process, } \\
\text { learning directed on } \\
\text { reflecting on } \\
\text { cognitive patterns }\end{array}$ & $\begin{array}{l}\text { Enhancing alertness to } \\
\text { outside world and } \\
\text { influencing on } \\
\text { cognitive patterns }\end{array}$ & $\begin{array}{l}\text { Concept mapping } \\
\text { Mind mapping and other idea } \\
\text { generation techniques }\end{array}$ \\
\hline $\begin{array}{l}\text { Students with } \\
\text { action approach }\end{array}$ & $\begin{array}{l}\text { Effectuation, } \\
\text { learning directed on } \\
\text { reflecting on } \\
\text { behavior patterns }\end{array}$ & $\begin{array}{l}\text { Enhancing } \\
\text { entrepreneurial venture } \\
\text { creation process }\end{array}$ & $\begin{array}{l}\text { Putting students into the } \\
\text { process in which they create } \\
\text { and try to exploit opportunities } \\
\text { in order to experience venture } \\
\text { creation processes }\end{array}$ \\
\hline
\end{tabular}

As Table 8 indicates, identifying the differences in different approaches makes possible to adopt different approaches and tools in learning interventions. The findings carry an important message of diversity, but also give some ideas to break the barriers between teachers' hesitation on how to teach different approaches. To underline these opportunities we next complete our study by drawing conclusions from the whole process and then summarizing its implications to theory and practice. 


\section{Conclusions and implications for theory and practice}

Our aim was to better understand different approaches to opportunity process and their impact on learning opportunity competences. We argued that different processes lead to a different understanding of the learning process and improving learning practices requires that we understand how the differences between the definitions of opportunity and opportunity process influence learning. This was demonstrated first by identifying the differences in understanding of opportunity and its process as well as differences in the nature of human involvement and then based on these criteria we developed three different approaches to opportunity identification. Then, by adopting a case study method and pattern matching analyzing logic we investigated in two phases how students understand what opportunities are in the new venture creation process categorizing their understanding according to these three approaches and then studying how these differences emerge in students' understanding of learning opportunity competences. The outcome of this process was a three-approach construct of opportunity identification process and some concrete suggestions on how to enhance opportunity identification competences in each construct.

Our basic claim about the diversity instead of uniformity of opportunity identification processes thus seems to be quite valid. This implies also practicing diversity in teaching opportunity process.

However, even more valid is our claim that more research is needed in the nexus of learning and opportunity identification, since our research has many limitations and it is more a small explorative pilot study to identify differences and their consequences than a profound and comprehensive study of three approaches. Thus theoretical generalization in this study can be seen as only providing ideas for that but not as yet leading to generalization.

The study has its limitations, especially in the methodological and empirical part. Firstly, we decided on the pattern-matching concept in our methodology. This strategy has not been effectively used in entrepreneurship research before. However, given its usefulness in other research domains, we adopted it without knowing the extent to which the methodological problems that could be associated with in entrepreneurship research. Hence future research in the entrepreneurship domain should encourage the use of this strategy to prove its applicability. Secondly, the sample includes students who already have their own enterprises and therefore we can categorize them as entrepreneurs and those without any entrepreneurial experiences. Thus the experience and motivation of the students could be quite different 
depending on their interest and level of commitment to entrepreneurship. However, as the initial idea of the study was to have all 16 students in the study at the beginning of their master's program in entrepreneurship, we could not effectively control for this, which could have an impact on the result. Hence, future research may need to take into consideration the composition of the respondents in terms of their prior experiences and knowledge in entrepreneurship.

Also, deeper and broader knowledge on our informants' backgrounds would enrich our understanding of opportunity process. If we could follow the students and their "putting ideas into life" we would know more about the opportunity process itself. The next issue we consider is whether the informants are diverse enough to permit conclusions. We believe that more comprehension of their opportunity process enriches our knowledge of the three approaches to opportunities identified.

However, our limitations sow a seed for further research. We may try to follow another case with other students and compare the findings or we may do a follow-up study with the same group of students and then, from a longitudinal perspective, study their opportunity processes. More profound research on a particular approach and its consequences for teaching practice is also recommended. Developing teaching interventions in light of the findings from our study it is still a challenge in research and practice. 


\section{References:}

Aaltio-Marjosola, I. (2002). Case-tutkimus. (Case research). Metodix. Available online www.metodix.com, January 1st , 2005.

Aldrich, H., Zimmer, C. (2006). Entrepreneurship through social networks. In D. Sexton, and R. Smilor (Eds.), The art and Science of Entrepreneurship (3-23). Cambridge, M.A: Ballinger.

Alsos, G. A., Kaikkonen, V. (2004). Opportunity recognition and prior knowledge: a study of experienced entrepreneurs, NCSB 2004 Conference, $13^{\text {th }}$ Nordic Conference on Small Business Research.

Alvarez, S.A., Barney, J.B. (2007). Discovery and creation: alternative theories of entrepreneurial action. Strategic Entrepreneurship Journal 1: 11-26 (2007), pp.11-26.

Ardichvili, A., Cardozo, R., and Ray, S. (2003). A theory of entrepreneurial opportunity identification and development. Journal of Business Venturing, 18(1), 105-123.

Baker T., Nelson, R and Arrow, J. (2005). Creating something from nothing: Resource constructing through entreprenerutial bricolage. Administrative Scinece Quarterly. 50: 329-366.

Barney, J. B. (1986). Strategic Factor Markets: Expectations, Luck, and Business Strategy. Management Science, 32, pp 1231-41.

Baron R. (2006). Opportunity Recognition as Pattern Recognition: How Entrepreneurs "Connect the Dots" to Identify New Business Opportunities, Academy of Management Perspectives, 20, 104-119.

Cantillon, R. (1931). Entrepreneur \& Economist, MacMillan, London.

Carrier, C.(2007). Strategies for teaching entrepreneurship: what else beyond lectures, case studies and business plans? In A. Fayolle (Ed.), Handbook of research in entrepreneurship education (Vol. 1, pp. 143-172). Cheltenham: Edward Elgar.

Casson, M. (1982): The Entrepreneur - An Economic Theory, 2nd ed., Edward Elgar: Cheltenham, UK, 2003.

Choi, Y. R., \& Shepherd, D. A. (2004). Entrepreneurs' decisions to exploit opportunities. Journal of Management, 30(3), 377-395. doi:10.1016/j.jm.2003.04.002.

Choi, Y.B 1993: Paradigms and Conventions: Uncertainty, decision making and entrepreneurship. Ann Arbor: University of Michigan Press.

Corbett, A. (2005). Experiential learning within the process of opportunity identification and exploitation. Entrepreneurship Theory and Practice, 29(4), 473-491.

Corner P.D., Ho M. (2010). How Opportunities Develop in Social Entrepreneurship?, Entrepreneurship Theory and Practice, July 2010, 635-659. 
Denzin, N. (1984). The research act. Englewood Cliffs, NJ: Prentice Hall.

DeTienne, D. R., Chandler, G. N. (2004). Opportunity identification and its role in the entrepreneurial classroom: a pedagogical approach and empirical test. Academy of Management Learning and Education, 3(3), 242-257.

Drucker, P. F.(1998). The discipline of innovation. Harvard Business Review 80 (8), 95-102.

Eckhardt, J.T., Shane, S.A. (2003). Opportunities and entrepreneurship. Journal of Management, 29(3), 333-349.

Eisenhardt, K.M. (1989), Building theories from case study research, Academy of Management Review, Vol. 14 pp.532-50

Fiet, J.O. (2000). The pedagogical Side of entrepreneurship Theory. Journal of business venturing, 16, 2, 101117.

Flyvbjerg, B. (2006). Five misunderstandings about case-study research. Qualitative Inquiry, vol 12, No. 2: 219 245.

Gaglio, C. (2004). The Role of Mental Simulations and Counterfactual Thinking in the. Opportunity Identification Process. Entrepreneurship: Theory and Practice, 28(6), 533-553.

Gaglio, C. M., Katz, J. A. (2001). The Psychological Basis of Opportunity Identification: Entrepreneurial Alertness. Small Business Economics, 16(2), 95-111.

Gartner, W. 1985. A conceptual framework for describing the phenomenon of new venture creation. Academy of Management Review, 10(4): 696-706.

Gartner, W., Carter, N., Hills, G. (2003). The language of opportunity, in Steyaert, C., Hjorth, D. (Eds), New Movements in Entrepreneurship, Edward Elgar, Cheltenham, pp.103-24.

Gunning, J.P. (1996). The old and newsubjectivism. http:www.gunning.cafeprogressive.comsubjectimean_subold_new.htm 22.2.2005

Hartley, J.F. (1997). Case studies in organizational research: A Practical Guide, London:Sage, pp. 208-29.

Holcombe, R. G, (2003). The Origins of Entrepreneurial Opportunities. The Review of Austrian Economics, Springer, vol. 16(1), pages 25-43, March

Huber, G.P. (2001). Transfer of knowledge in knowledge management systems: Unexplored issues and suggested studies. European Journal of Information Systems, 10, 72-79.

Kaplan, T. (2000), University-sponsored family business programs: Program characteristics, perceived quality and member satisfaction," Entrepreneurship Theory and Practice, spring 24(3): 5-23. 
Kirby, D. (2007). Changing the entrepreneurship education paradigm. In A. Fayolle (Ed.), Handbook of research in entrepreneurship education (Vol. 1, pp. 21-45). Cheltenham: Edward Elgar.

Kirzner I, M. (1973). Competition and Entrepreneurship. Chciago, IL: University of Chicago Press

Kirzner, I. M., (1963). Entrepreneurship and the Market Approach to Development, New Individualist Review, Summer, 20-28.

Kirzner, I. (1979) Perception, Opportunity and Profit. Chicago, IL: University of Chicago Press.

Kirzner, I. (1997) "Entrepreneurial discovery and the competitive market process: An Austrian approach." Journal of Economic Literature. 35, 60-85.

Lumpkin, G.T, Lichtenstein B.B. (2005). The role of Organizational Learning in the Opportunity-Recognition Process. Entrepreneurship Theory and Practice, July 2005.

McMullen, J.S., Plummer, L.A., Acs, Z.J., (2007).What is an Entrepreneurial Opportunity?, Small Business Economics, 2007 (28), 273-283.

Mises, Ludwig von (1949). Human Action: A Treatise on Economics (4th ed.), San Francisco: Fox \& Wilkes.

Pauwels, P. \& Matthyssens P. (2003). "The dynamics of international market withdrawal”. in State of Art of Research in International Marketing, (ed.), S. Jain, Cheltenham, UK and Northampton, MA, USA: Edward Elgar, forthcoming

Pauwels, P. \& Matthyssens P. (2004). "The Architecture of Multiple Case Study Research in International Business." In Handbook of Qualitative Research Methods for International Business (ed.) R. MarschanPiekkari and C. Welch. Edward Elgar.

Saks, N.T., Gaglio C.M. (2002). Can Opportunity Identification be Taught? Journal of Enterprising Culture, 10, pp.313-347.

Sandye, G-P. (2006). Modern Austrian Economics: Archaeology of a Revival, Journal of Economics Literature, xxxv, 60-85.

Sarasvathy, S. (2001). Causation and effectuation: Toward a theoretical shift from economic inevitability to entrepreneurial contingency. Academy of Management Review 26(2), 243-263.

Sarasvathy, S.D., Dew, N., Velamuri, S.R., Venkataraman, S. (2003). Three Views of Entrepreneurial Opportunity. (in) Z.J. Acs and D.B. Audretsch (eds.), Handbook of entrepreneurship Research, Kluwer Academic Publishers, pp. $141-160$.

Shane, S. (2003). A General Theory of Entrepreneurship. The Individual-Opportunity Nexus. Cheltenham: Edward Elgar, 2003. 
Shane, S. A. (2000). Prior knowledge and the discovery of entrepreneurial opportunities. Organization Science, $11,448-469$.

Shane, S., Venkataraman, S. (2000). The Promise of Entrepreneurship as a Field of Research.The Academy of Management Review, 25(1), 217-226.

Singh, R. P., G. E. Hills, and G. T. Lumpkin (1999). New Venture Ideas and Entrepreneurial Opportunities: Understanding the Process of Opportunity Recognition, Proceedings of the 1999 U.S. Association for Small Business and Entrepreneurship, 657-671.

Stake, R.E. (1995). The art of case study research. Thousand Oaks: SAGE Publications.

Troch im, W.M.K. (2006). “The Research Methods Knowledge Base”, http://www.socialresearchmethods.net/kb/pmconval.php

Venkataraman, S. (2003). 'Foreword'. In Shane, S., A General Theory of Entrepreneurship. The IndividualOpportunity Nexus, Northampton, MA: Edward Elgar.

Venkataraman, S., Sarasvathy, S. D. (2001). Strategy and Entrepreneurship: Outlines of an untold story. In M. A. Hitt, R. E. Freeman \& J. S. Harrison (Eds.), Handbook of Strategic Management (pp. 650-668). Oxford, UK: Blackwell.

Weick, K. (1979). The social psychology of organizing. Addison-Wesley Publishing Company.

Yin, R. K. (1984). Case study research: Design and methods. Newbury Park, CA: Sage.

Zietsma, C. (1999). Opportunity knocks—or does it hide? An examination of the role of opportunity recognition in entrepreneurship. Frontiers of Entrepreneurship, 242-256. 